\begin{tabular}{c} 
Journal of Business School \\
$2019,2(4): 53-68$ \\
DOI: $10.26677 /$ TR1010.2019.107 \\
Journal Homepage: $\underline{\text { https://www.journalbusiness.org }}$ \\
\hline
\end{tabular}

\title{
Assessing The Use of E-Commerce in Heritage Tourism Marketing: Case of National Theatre And National Musuem, Lagos, Nigeria
}

\author{
Adeleke Bola Olusola \\ Department of Transport and Tourism Studies, Redeemer's University, Ede \\ adelekeb@run.edu,ng
}

\section{Ogunsusi Kayode}

Department of Transport and Tourism Studies, Redeemer's University, Ede

\author{
Adeosun Folasade Christianah \\ Department of Transport and Tourism Studies, Redeemer's University, Ede
}

\begin{abstract}
The increased commercialization of tourism through E-commerce is now being used to attract and serve relevant target groups. Because of the competitive challenges in today's tourism business, heritage tourism and E-commerce have to work together in order to make the industry stand the test of time. Study was conducted in National Theatre (NT) and National Museum (NM), Lagos Nigeria to evaluate the use of E-commerce by the two destinations. Data were analysed using qualitative descriptive analysis, One-way Analysis Of Variance, and multivariable linear regressions. Results of the study showed that $96.6 \%$ of the respondents in NT and $96.4 \%$ in NM agreed that the use of internet established interactive relationship between customers. In NT, $96.7 \%$ of the respondents agreed that it is possible to book online packages using E-commerce, while $99.3 \%$ agreed to this in Nm. In NT, five constructs out of eleven were significant in enhancing the use of E-commerce in the destination, while none was significant for NM. The overall strengths of relationship between educational statuses of tourists were weak in predicting efficient use of e-commerce for both destinations. However, NM was able to better predict the efficient use of e-commerce than NT. The F-test overall showed that the relationships between educational status and efficient use of e-commerce in NT and NM were not statistically significant. The result of multivariable linear regressions further showed that for the two destinations, the educational status of tourists predicted that the use of e-commerce was not efficient in the marketing of their tourism products and services. The managements of NT and NM, and by extension all other heritage attractions should therefore fashion out strategies on the adoption and efficient use of e-commerce in marketing their institutions in order to enhance service delivery, improve efficiency, maximize and maintain long-term profitability.
\end{abstract}

Keywords: E-commerce, Heritage, Lagos, Marketing, Museum, Theatre 


\section{Introduction}

\section{Background}

The heritage tourism industry is a tool that can be used to turn around the economic fortunes of any region or nation by its capacity to attract visitors from outside a host community through the arrays of historical, artistic, scientific or lifestyle/heritage that the industry has to offer (Silberberg 1995). To remain competitive in today's business environment, there is the need for heritage tourism firms to go extra miles in expanding their customer base. This to a large extent is hinged on ability to acquire and utilize up to date information in the management and marketing process. Tourism depends largely on the amount of information that tourists are about to gather about any tourist destination (Buhalis, 1998).

It is not a farfetched fact that the use of internet is rapidly growing day by day with millions if not billions of people being online 24hours. Therefore, the internet can be exploited as a tool promoting and opening up competitive opportunities for the tourism industry through the application of e-commerce (Alsarayreh, M. N., Jawabreh, O, A. A., Alkharabsheh, K. and Eldahamsheh, M. 2011). E-commerce, a process of exchanging financial and informational transactions through computerized electronic network with internet access can enable the transactions of networked economy around the world, as well as empower organizations to collaborate virtually (Kalakota and Whinston, 1997; Timmers, 1999; Kalakota and Robinson, 2001; Turban, E., King, D., Lee, J. K., Liang, T. and Turban, D. C., 2015). Use of internet has expanded tourism global customer reach and has hitherto created a more competitive environment with greater propensity for tourism business development (Paraskevas, 2005; Berné, C., García-González, M., García-Ucedac, M.E. and Múgica, J.M., 2015). Tourism businesses without access to the internet may likely not benefit from the provisions from eservices and could gradually edge out of global markets (Pimenidis, E., Bolissian, J.M., Iliadis, L. and Andreopoulou, Z., 2006, cited in Stiakakis and Georgiadis, 2011). Tourism businesses not utilizing e-commerce tools could be gradually driven out of competition from global markets (Pimenidis et al., 2006 cited in Stiakakis and Georgiadis, 2011).

There has been calls for the attention of policy makers to give priority to business-oriented heritage organizations in order to drive the tourism industry for national economic development (Gilmore and Rentschler, 2002; Hall, 2005; Bramwell, 2011; Manzuma-Ndaaba, N. M., Harada, Y. and Islam, A., 2014). Hoffman and Novak (1997) asserted the uniqueness of the Web as it stands out from traditional marketing channels. The managements of many tourism firms are, however, not aware of the numerous opportunities offered by e-commerce through the internet in reducing cost of advertisement, boosting sales, and getting new customers. The major challenge in today's business with regards to communication and customer satisfaction indicates that there should be a synergy between the tourism industry and use of e-commerce (Gratzer, M., Winiwarter, W. and Werthner, H., 2002). There are quite a number of tools embedded in ICT that can enable tourism organizations to manage and market their businesses effectively and efficiently (Buhalis, 2003; O'Connor and Murphy, 2004). Heritage tourism is certain to become reliant on e-commerce for marketing of products and services. National Theatre and National Museum as part of their marketing strategies has not put into full practice the use of e-commerce in getting to their customers. This study is therefore aimed at the assess the use of e-commerce platform in the marketing of heritage tourism industry in National Theatre and National Museum Lagos, Nigeria.

The specific objectives of the study are to:

1. Asses the use of e-commerce platform in managing National Theatre and National Museum. 
2. Compare the use of e-commerce between National Theatre and National Museum.

\section{Hypotheses}

The following hypotheses were formulated in line with statement of the problems:

1. Ho: The marketing of heritage tourism destination is not significantly enhanced by the use of e-commerce

2. Ho: Efficient use of e-commerce is not significantly predicted by the educational status of tourists

\section{LITERATURE REVIEW}

E-commerce is a term that is used in describing the process of buying, selling, transferring, or exchanging products, services, and/or information through computer networks, principally the internet (Singer, P., Ferri, M. A., Aeillo, L. and Cacia, C., 2010); Turban et al. (2006). Getting to know about any tourist destination is a function of the amount of information a tourist can access about the destination. As "confidence goods", tourists' decision can only be informed by the information that they get (Werthner and Ricci, 2004). This information is right at the centre of the tourism product (Zhou and DeSantis, 2005). These days, tourism is being enveloped in a web of electronic environment, where only the knowledge of ICT can help in serving customers with greater efficiency in order to maximize profits (Buhails, 1998).

The use of e-commerce can give tourists the chance to get information about new tourism services and products. A lot of other opportunities and advantages come with the use of ecommerce in tourism. Among these are the speed and ease with which tourists can access destinations and get relevant information about price and facilities (Werther and Klein, 1999). Widened market base is another of such advantage (Metzger, 2004) which will give the tourism industry an opportunity to grow at relatively low cost (Singer, P., Ferri, M. A., Aeillo, L. and Cacia, C., 2010). Apart from this, distribution, marketing and operational benefits are also realizable from e-commerce (Hoffman and Novak, 1997). The relatively little cost attached to online transactions can also help to reduce transaction costs (Kiggundu, 2002). E-commerce according to the finding by MCIvor et al. (2000) can assist in developing collaborations with key suppliers in product development as the tourism firms share cross-functional information on a wide range of issues. The time used in searching for information as well as for transaction can also be drastically reduced with the use of e-commerce (Schaeffer, 2003). E-commerce also enhances bookings of tourism products and services, and how tourists communicate and interact with one another (Saleh et al., 2011).

Among many other factors that can facilitate individualistic and specialized forms of tourism such as cultural heritage tourism owing to its high level of attractiveness as embedded in the travel experience (Boyd, 2002) is information technology (Rayman-Bacchus and Molina, 2001), particularly the use of e-commerce in accessing tourism products and services. If properly harnessed the heritage tourism industry can enhance the economic development of the area where it is located (Silberberg 1995). Such travel is focused upon experiencing cultural environments, including landscapes, the visual and performing arts and special lifestyles, values, traditions, and events. 


\section{METHODOLOGY}

\section{Data collection}

Qualitative method was used to evaluate the use of e-commerce by the two destinations. Quantitative method was, however, used to test hypotheses for the efficient use of information technology and e-commerce by tourism firms.

The perception of heritage tourists in Lagos Nigeria were measured using structured questionnaire. The sample size of the respondents was determined using the Yamane formula (1967) as used by Israel (2010). The sample size of 150 was obtained using the formula to calculate the size from extrapolated figure of 240 visitors that visit National Theatre on weekly basis. The 240 figure was arrived at during reconnaissance survey of the two destinations on average weekly visitations to the destinations. A random sample of tourists who visited National Theatre and National Museum was carried out. A total of 300 copies of questionnaire with 150 copies in each of the destinations were administered on tourists of both destinations. Close-ended questions were used to gather data on demographic characteristics and efficiency of use of information technology by tourists. Efficiency of use of e-commerce was evaluated using a four-point Likert scale of strongly agreed to strongly disagree, which was later scaled down to the levels of agreement and disagreement for ease of presentation.

Simply because of tourism growth and its contribution to economic boom in many regions, many studies have been directed only to simple economic variables (Dwyer et al., 2000; Dwer et al., 2001; Kayar and Kozak, 2010; Zhang et al., 2011; Candela, 2012, Chou, 2013), which has downplayed the significance of other variables particularly predicting destination performance by using demographic variables. Dang and Huang (2014) used demographic characteristics to compare overall satisfaction and it was found that nationality, age, occupation and monthly income has no significant impact on it, but, significant difference in satisfaction was found by education. Therefore, for this study, in the regression analysis hypothesis was formulated about the means of the groups on the dependent variable of educational status of tourists. The dependent variable differentiated individual tourists on some quantitative (continuous) dimensions.

The Yamane formula is given as: -

$\mathrm{n}=\mathrm{N} / \mathrm{N}\left(1+\mathrm{Ne}^{2}\right)$

Where

$\mathrm{n}=$ corrected sample size, $\mathrm{N}=$ population size, and $\mathrm{e}=$ Margin of error $(\mathrm{MoE}), \mathrm{e}=0.05$ based on the research condition.

\section{Data Analysis}

Qualitative descriptive analysis was used to verbally summarize information on demographic profile. Multivariable regression analysis was carried out to predict the efficiency of use of ecommerce by the educational status of respondents in National Theatre and National Museum.

This tool was used so as to study the effect of multiple variables on the dependent variable instead of using a single independent variable which is not alone sufficient to explain the dependent variable $Y$. In the multivariable regression model, the dependent variable is described as a linear function of the independent variables $X_{i}$, as follows: $Y=a+b 1 \times X 1+b 2 \times$ $X_{2}+\ldots+b_{n} \times X_{n}$. The model permits the computation of a regression coefficient $b_{i}$ for each independent variable $\mathrm{X}_{\mathrm{i}}$.

Regression line for multivariable regression 
$\mathrm{Y}=\mathrm{a}+\mathrm{b}_{1} \times \mathrm{X}_{1}+\mathrm{b}_{2} \times \mathrm{X}_{2}+\ldots+\mathrm{b}_{\mathrm{n}} \times \mathrm{X}_{\mathrm{n}}$

Where;

$\mathrm{Y}=$ dependent variable

$\mathrm{X}_{\mathrm{i}}=$ independent variables

$\mathrm{a}=$ constant $(\mathrm{y}$-intersect)

$b_{i}=$ regression coefficient of the variable $X_{i}$

\section{RESULTS AND DICUSSION}

\section{Demographic Profile of Tourist to National Museum}

The Demographic profile of respondents in National Museum revealed that male respondents were $50.7 \%$, while females were $49.3 \%$. Most respondents $(83.3 \% 0$ had tertiary education, $8.7 \%$ had secondary education, while $2.7 \%$ had primary education, as $5.3 \%$ had other qualifications. The age distributions of respondents showed that majority $(40.0 \%)$ was within $26-35$ years, 18 25 years $(30.7 \%), 36-45$ years $(18.0 \%)$, $46-55$ years $(6.7 \%)$, 56-65years $(3.3 \%)$, while $1.3 \%$ were above 65years in age. Most respondents were Nigerians (99.3\%) while foreigners were just $7 \%$. Demographic Profile of Tourist to National Theatre

The Demographic profile of (tourists) respondents is National Theatre revealed that most respondents were males $(58.4 \%)$. Most of them (75.5\%) had tertiary education, $14.8 \%$ had secondary education, while $1.3 \%$ had primary education, as $9.4 \%$ was recorded for others. The age distribution of respondents showed that majority (36.2\%) were within 26-35 years of age, $28.9 \%$ within the age range of $18-25$ yeas, $22.8 \%$ within $36-45$ years, $10.1 \%$ within the age of $46-$ 55years, while $2.0 \%$ was within the age of 56-65 years. Most respondents were Nigerians are $(99.3 \%)$, while $7 \%$ were foreigners.

Men participated more in heritage tourism than women in National Theatre and National Museum which agreed with the findings of Mason and Cheyne (2000) and Harrill and Potts (2003) who found more women opposed to tourism development. Data on educational background of respondents revealed that in the two destinations under consideration, most of the respondents had tertiary education. This implies that most of the respondents were well educated. This finding agreed with that of Ayeni (2013) on the educational background of respondents in a social survey as well as the finding of Bello et al. (2017) in which education was found as one of the limiting factors affecting community participation in ecotourism.

\section{Use of E-Commerce by Heritage Tourism Firms}

The result in Table 1 showed the level of agreement by respondents on the use of E-commerce in NT and NM. Almost the same number of respondents in NT (89.2\%) and NM (97.3\%) agreed that the destinations had their own websites, as about the same number of respondents in National Theatre $(88.6 \%)$ and NM $(99.3 \%)$ also agreed that e-commerce provides better information through the internet. Also, $96.6 \%$ of the respondents in National Theatre and $96.4 \%$ in National Museum agreed that the use of internet establishes interactive relationship between customers. In National Theatre $92.6 \%$ of the respondents agreed that the internet saves time for providing tourism services, while only $96.7 \%$ agreed to this in National Museum. Agreement by respondents on possibility of booking online packages using e-commerce was $96.7 \%$ in National Theatre, while it was $99.3 \%$ in National Museum, even though as $24.8 \%$ and $19.3 \%$ of the respondents respectively in National Theatre and National Museum agreed that getting services through the internet wastes a lot of time. Notwithstanding, $90.0 \%$ and $95.3 \%$ of the respondents respectively in National Theatre and National Museum agreed that the internet 
saves cost on accessing information with the use of e-commerce. On getting services from destination, $85.9 \%$ of the respondent in National Theatre agreed that the process was simplified using online means, while $96.0 \%$ agreed to this in National Museum. But, only $79.2 \%$ of the respondents agreed that the process of booking accommodation online was more convenient than through travel agents in National Theatre, while it was $96.0 \%$ in National Museum. Furthermore, $87.9 \%$ of the respondents agreed to the possibility of accessing new products from the website of the destination, while $99.3 \%$ agreed to this in National Museum. In National Theatre and National Museum, $91.3 \%$ and $98.6 \%$ of the respondents respectively agreed to introduce their friends to e-commerce for tourism products and services.

With the exception of the variable that "getting services through the internet waste a lot of time" that did not get majority agreement from the respondents, the remaining variables enjoyed considerably high level of agreement from the respondents. This in other words implies that the variables were to a large extent used in accessing e-commerce in both heritage tourism destinations. This may open quite a number of opportunities for the heritage tourism industry.

The prediction by Carlsson (2010) that social media will be the order of the day for branding and onward integration into organizations cannot be waved aside. This is apt to say that tourism destinations should begin to lay much emphasis on web design for their sites as a way of getting customers and communicating with them (Webber, 2007). Widened market base is one of such (Metzger, 2004) which will give the tourism industry an opportunity to grow at relatively low cost. Apart from this, distribution, marketing and operational benefits are also realizable from e-commerce (Hoffman and Novak, 1996). The relatively little cost attached to online transactions can also help to reduce transaction costs (Kiggundu, 2002). E-commerce according to the finding by MCIvor et al. (2003) can assist in developing collaborations with key suppliers in product development as the tourism firms share cross-functional information on a wide range of issues. The time used in searching for information as well as for transaction can also be drastically reduced with the use of e-commerce (Schaeffer, 2003).

Table 1. Use of E-commerce By National Theatre and National Museum

\begin{tabular}{|l|l|l|l|l|l|l|l|}
\hline & & \multicolumn{2}{|l|}{ National Theatre } & \multicolumn{2}{l|}{ National Museum } \\
\cline { 3 - 8 } & & \multicolumn{2}{|l|}{ Level of Agreement } \\
\hline S/No & & $\begin{array}{l}\text { Agreem } \\
\text { ent }\end{array}$ & $\begin{array}{l}\text { Disagree } \\
\text { ment }\end{array}$ & Total & $\begin{array}{l}\text { Agree } \\
\text { ment }\end{array}$ & $\begin{array}{l}\text { Disagree } \\
\text { ment }\end{array}$ & Total \\
\hline 1 & $\begin{array}{l}\text { This tourism destination has its } \\
\text { own website }\end{array}$ & 89.20 & 10.80 & 100 & 97.30 & 2.70 & 100 \\
\hline 2 & $\begin{array}{l}\text { E-commerce provides better } \\
\text { information through the internet }\end{array}$ & 88.60 & 11.40 & 100 & 99.30 & 0.70 & 100 \\
\hline 3 & $\begin{array}{l}\text { Use of internet establish } \\
\text { interactive relationship between } \\
\text { customers }\end{array}$ & 96.60 & 3.40 & 100 & 96.40 & 3.60 & 100 \\
\hline 4 & $\begin{array}{l}\text { The internet saves time for } \\
\text { providing tourism services }\end{array}$ & 92.60 & 7.40 & 100 & 96.70 & 3.30 & 100 \\
\hline 5 & $\begin{array}{l}\text { It is possible to book online } \\
\text { packages }\end{array}$ & 96.70 & 3.10 & 100 & 99.30 & 0.70 & 100 \\
\hline
\end{tabular}




\begin{tabular}{|c|c|c|c|c|c|c|c|}
\hline 6 & $\begin{array}{l}\text { Getting services through the } \\
\text { internet waste a lot of time }\end{array}$ & 24.80 & 75.20 & 100 & 19.30 & 80.70 & 100 \\
\hline 7 & $\begin{array}{l}\text { The internet saves cost on } \\
\text { accessing information }\end{array}$ & 90.00 & 10.00 & 100 & 95.30 & 4.70 & 100 \\
\hline 8 & $\begin{array}{l}\text { The process of getting services } \\
\text { from destination is simplified } \\
\text { using online means }\end{array}$ & 85.90 & 14.10 & 100 & 96.00 & 4.00 & 100 \\
\hline 9 & $\begin{array}{l}\text { The process of booking } \\
\text { accommodation online is more } \\
\text { convenient than through travel } \\
\text { agents }\end{array}$ & 79.20 & 20.80 & 100 & 96.00 & 4.00 & 100 \\
\hline 10 & $\begin{array}{l}\text { It is possible to access new } \\
\text { products from the website of } \\
\text { this tourism destination }\end{array}$ & 87.90 & 12.10 & 100 & 99.30 & 0.70 & 100 \\
\hline 11 & $\begin{array}{l}\text { I will introduce my friends to e- } \\
\text { commerce for tourism products } \\
\text { and services }\end{array}$ & 91.30 & 8.70 & 100 & 98.60 & 1.40 & 100 \\
\hline
\end{tabular}

Efficiency of Use of E-Commerce by Heritage Tourism Firms for Marketing Tourism Products

The efficiency of use of e-commerce by National Theatre and National Museum was evaluated using the following 11 constructs (Table 2):

(1) Tourism destination has its own website;

(2) e-commerce provides better information through the internet;

(3) Use of internet establishes interactive relationship between customers;

(4) The internet saves time for providing tourism services;

(5) It is possible to book online packages;

(6) Getting services through the internet wastes a lot of time;

(7) The internet saves cost on accessing information;

(8) The process of getting services from destination is simplified using online means

(9) The process of booking accommodation online is more convenient than through travel agent;

10) It is possible to access new products from the website of this tourism destination and;

11) Tourists will introduce friends to e-commerce for tourism products and services.

For National Theatre, the result of ANOVA showed that the p-value for the following constructs were greater than 0.05 , and so their null hypotheses were accepted (not significant) and it was concluded that the group means of the constructs were not statistically different, and so were not significant in marketing of tourism products and services in the destination: the tourism destination has its own website $(\mathrm{F}(6,142)=0.651, \mathrm{P}=0.689)$; use of internet establish 
interactive relationship between customers $(F(6,146)=2.610, p=0.0200)$; the internet saves time for providing tourism services $(\mathrm{F}(6,142)=1.094, \mathrm{p}=0.369)$; it is possible to book online packages $(\mathrm{F}(6,142)=0.887, \mathrm{P}=0.506)$; the process of booking accommodation online is more convenient than through travel agents $(\mathrm{F}(3,142)=1.569, \mathrm{P}=0.161)$; it is possible to access new products from the website of this tourism destination $(\mathrm{F}(6,142)=0.915, \mathrm{p}=0.486)$.

However, the p-value for the following constructs were less than 0.05 , thus their null hypotheses were rejected (was significant) and so it was concluded that the constructs were significant in marketing of tourism products and services in the destination: e-commerce provide better information through the internet $(\mathrm{F}(6,142)=2.610, \mathrm{p}=0.020)$; getting services through the internet wastes a lot of time $(\mathrm{F}(6,142)=2.947, \mathrm{p}=0.010)$; the internet saves cost on accessing information $(\mathrm{F}(6,142)=1.450, \mathrm{P}=0.0200)$; the process of getting services from destination is simplified using online means $(\mathrm{F}(6,142)=2.534, \mathrm{P}=0.023)$; tourist will introduce friends to e-commerce for tourism products and services $(F(6,142=3.149, p=0.006)$.

However, for National Museum none of the constructs had p-value that is less than 0.05 , so their null hypotheses were accepted (not significant) and so it was concluded that the constructs did not significantly enhance the use of e-commerce. So, e-commerce has not been efficient in the marketing of tourism products and services in National Museum.

The value of destination websites as a distribution channel in meeting the demands of customers in the tourism industry can never be over emphasized. As people interact on the ecommerce platform, they develop closer relationship (Buhalis, 2003). The e-commerce platform has also been recognized as a medium for selling tourism products and services (Morgan et al., 2001; Corbitt, 2003), and so there is the possibility of booking online packages for the two heritage destinations using the platform. Using the internet to sell tourism products and services is becoming more interesting and useful than through agents. Tourists have come to realize that it is possible for them to open up more on what they desire as they access tourism products through e-commerce which was attested to in the finding of (Noti, 2016). This is possibly why the electronic intermediaries are now being seen as potential threat to the services of traditional distributors (Madasu, 2013). When these intermediaries are eliminated, there could be a reduction in distribution costs.

Result of this study has thus revealed that in National Theatre, e-commerce provide better information through the internet, the internet saves cost on accessing information, the process of getting services from destination is simplified using online means, tourist will introduce friends to e-commerce for tourism products and services. However, getting services through the internet wastes a lot of time. The finding of this study on provision of better information through the internet is in tandem with that of MCIvor et al. (2000) in which e-commerce was found to provide cross-functional information for visitor needs through collaborations. On cost reduction in accessing information, this study has revealed that the use of e-commerce is cost effective which is in tandem with the finding of (Afuha, 2003; O'Connor). Also, this study has shown that respondents recognized that the process of getting services from destination is simplified using online means. This is in agreement with the finding of Lee and Lin (2005). This according to them makes the sales of tourism products and services to get the necessary boom if the use of e-commerce is internalized by the tourism firm. This study has shown that getting services through the internet wastes a lot of time. This according to Findings of Kartavianus and Napitupulu (2012) may be attributed to infrequent use of e-commerce, which always resulted into waste of time at those intermittent periods of use of e-commerce. Time wasted during these periods of use may lead to loss of revenue (Enz, 2003). The readiness of respondents to introduce friends to e-commerce for tourism products and services may be attributable to the various advantages inherent in the use of e-commerce which this study and the respondents 
have recognized. This finding on willingness to introduce friends to e-commerce agreed with that of Murphy et al. (2007) that friends and relatives have been recognized as promotion agents for destination selection through word-of-mouth marketing in the context of online communities.

Table 2. Efficiency of Use of E-commerce by Tourism Firms

\begin{tabular}{|c|c|c|c|c|c|c|c|c|c|c|c|}
\hline \multirow[t]{2}{*}{ S/No } & \multirow[b]{2}{*}{ Difference } & \multicolumn{5}{|c|}{ National Theatre } & \multicolumn{5}{|c|}{ National Museum } \\
\hline & & SS & Df & $\begin{array}{l}\text { Mean } \\
\text { Square }\end{array}$ & $\mathbf{F}$ & Sig. & SS & Df & $\begin{array}{l}\text { Mean } \\
\text { Square }\end{array}$ & $\mathbf{F}$ & Sig. \\
\hline \multirow[t]{3}{*}{1} & Between Groups & 1.64 & 6 & 0.27 & 0.65 & 0.69 & 0.37 & 7 & 0.05 & 0.17 & 0.99 \\
\hline & Within Groups & 59.49 & 142 & 0.42 & & & 43.82 & 142 & 0.31 & & \\
\hline & Total & 61.13 & 148 & & & & 44.19 & 149 & & & \\
\hline \multirow[t]{3}{*}{2} & Between Groups & 5.70 & 6 & 0.95 & 2.61 & 0.02 & 1.02 & 7 & 0.15 & 0.55 & 0.80 \\
\hline & Within Groups & 51.66 & 142 & 0.36 & & & 37.81 & 142 & 0.27 & & \\
\hline & Total & 57.36 & 148 & & & & 38.83 & 149 & & & \\
\hline \multirow[t]{3}{*}{3} & Between Groups & 1.32 & 6 & 0.22 & 0.71 & 0.64 & 2.94 & 7 & 0.42 & 1.41 & 0.21 \\
\hline & Within Groups & 43.87 & 142 & 0.31 & & & 42.32 & 142 & 0.30 & & \\
\hline & Total & 45.20 & 148 & & & & 45.26 & 149 & & & \\
\hline \multirow[t]{3}{*}{4} & Between Groups & 2.41 & 6 & 0.40 & 1.09 & 0.37 & 2.84 & 7 & 0.41 & 1.20 & 0.31 \\
\hline & Within Groups & 52.13 & 142 & 0.37 & & & 48.12 & 142 & 0.34 & & \\
\hline & Total & 54.54 & 148 & & & & 50.96 & 149 & & & \\
\hline \multirow[t]{3}{*}{5} & Between Groups & 1.61 & 6 & 0.27 & 0.89 & 0.51 & 1.67 & 7 & 0.24 & 0.89 & 0.51 \\
\hline & Within Groups & 42.98 & 142 & 0.30 & & & 37.83 & 142 & 0.27 & & \\
\hline & Total & 44.59 & 148 & & & & 39.49 & 149 & & & \\
\hline \multirow[t]{3}{*}{6} & Between Groups & 9.73 & 6 & 1.62 & 2.95 & 0.01 & 9.24 & 7 & 1.32 & 2.05 & 0.53 \\
\hline & Within Groups & 78.14 & 142 & 0.55 & & & 91.59 & 142 & 0.65 & & \\
\hline & Total & 87.87 & 148 & & & & 100.83 & 149 & & & \\
\hline \multirow[t]{3}{*}{7} & Between Groups & 3.88 & 6 & 0.65 & 1.45 & 0.02 & 0.90 & 7 & 0.13 & 0.37 & 0.92 \\
\hline & Within Groups & 63.25 & 142 & 0.45 & & & 48.89 & 142 & 0.34 & & \\
\hline & Total & 67.13 & 148 & & & & 49.79 & 149 & & & \\
\hline \multirow[t]{3}{*}{8} & Between Groups & 6.13 & 6 & 1.02 & 2.53 & 0.02 & 3.80 & 7 & 0.54 & 1.59 & 0.14 \\
\hline & Within Groups & 57.20 & 142 & 0.40 & & & 48.48 & 142 & 0.34 & & \\
\hline & Total & 63.33 & 148 & & & & 52.27 & 149 & & & \\
\hline 9 & Between Groups & 5.19 & 6 & 0.87 & 1.57 & 0.16 & 2.43 & 7 & 0.35 & 1.10 & 0.37 \\
\hline
\end{tabular}




\begin{tabular}{|l|l|l|l|l|l|l|l|l|l|l|l|}
\hline \multirow{2}{*}{} & Within Groups & 78.300 & 142 & 0.55 & & & 44.91 & 142 & 0.32 & & \\
\cline { 2 - 12 } & Total & 83.490 & 148 & & & & 47.34 & 149 & & & \\
\hline 10 & Between Groups & 2.23 & 6 & 0.37 & 0.92 & 0.49 & 0.51 & 7 & 0.07 & 0.28 & 0.96 \\
\cline { 2 - 13 } & Within Groups & 57.60 & 142 & 0.41 & & & 36.055 & 142 & 0.25 & & \\
\cline { 2 - 13 } & Total & 59.83 & 148 & & & & 36.56 & 149 & & & \\
\hline 11 & Between Groups & 5.89 & 6 & 0.98 & 3.15 & 0.01 & 2.10 & 7 & 0.30 & 1.03 & 0.41 \\
\cline { 2 - 13 } & Within Groups & 44.25 & 142 & 0.31 & & & 41.25 & 142 & 0.29 & & \\
\cline { 2 - 12 } & Total & 50.13 & 148 & & & & 43.34 & 149 & & & \\
\hline
\end{tabular}

\section{Efficient Use of E-Commerce As Predicted By Tourists' Educational Status}

The results of multivariable linear regressions used in testing hypotheses for predicting the use of e-commerce by the educational statuses of tourists to National Theatre and National Museum are as presented in Table 3. When all 11 factors that predicted efficiency of use of ecommerce were regressed with the dependent variable which was educational status at tolerance limit of 0.00 when all predictors in the model were set to zero, (Table 3). The overall strengths of the relationships were weak for both National Theatre $(R=0.282)$ and National Museum $(R=0.240)$. The percentage variance of prediction was explained by only $7.8 \%$ and $55.8 \%$ of the independent variables respectively in National Theatre and National Museum. The F-values stood at 1.063 in National Theatre, and 0.670 in National Museum. The F-tests overall for both destinations showed that, the relationships between educational status and efficient use of e-commerce were not statistically significant. This implies that the F-test has determined that the proposed relationship between the response variable, i.e., educational statuses of tourists and the set of predictors was not statistically significant, and so predicted that the use of e-commerce was not efficient.

The result of multiple regression showed that for National Theatre and National Museum, the $\mathrm{p}$-values for the following constructs were greater than 0.05 , and so their null hypothesis were accepted (not significant), and so it was concluded that the educational status of tourists in the destinations did not significantly predict that: the tourism destination has its own website; ecommerce provides better information through the internet; use of internet establishes relationship between customers; the internet saves time providing tourism services; it is possible to book online packages; getting services through the internet waste a lot of time; the internet saves cost on accessing information; the process of getting services from destination is simplified using online means; the process of booking accommodation online is more convenient than through travel agents; it is possible to access new products from the website of this tourism destination; tourists will introduce friends to e-commerce for tourism products and services.

The model for this study revealed that the gaps between the observed value for prediction and each of the expected values for prediction are wide. This implies that the variables that were not significant and so not good enough to predict the efficient use of e-commerce. The overall strengths of relationship in this study which were weak are a poor measure of the strength of relationship between the models of this study and the dependent variables. The very low values of $\mathrm{R}^{2}$ in the regression model also indicate that the variables that were not significant cannot predict the efficient use of e-commerce with high precision and validity. These variables 
according to the finding of Ekinci and Hosany (2006) provide evidence for the predictive validity of the efficient use of e-commerce by the educational statuses of tourists.

The result of this study showed that the overall strength of the models for predicting the efficient use of e-commerce was weak for both destinations, but, National Museum was able to better predict the efficient use of e-commerce than National Theatre. Therefore, the use of educational variable could be seen as a significant factor in evaluating the use of e-commerce especially in National Museum. This result therefore is in tandem with the finding of Dang and Huang (2014).

The educational status of respondents in both destinations predicted that the use of e-commerce was not efficient in the two destinations, and this may not be unconnected with the high level of knowledge and experience of the educated elites who mostly had tertiary educations. The educational qualifications of the respondents have thus put them in vantage positions to better interpret the perceived benefits derivable from the use of e-commerce. According to Connelly et al. (2016), measures of education as part of many sociological analyses are powerful predictors of a diverse range of social outcomes.

Table 3. Educational Status of Tourists and Its Impact on Efficient Use of E-commerce

\begin{tabular}{|c|c|c|c|c|c|c|c|c|c|c|c|}
\hline \multirow{3}{*}{ S/No } & \multirow{3}{*}{ Model } & \multicolumn{4}{|c|}{ Coefficients $^{\mathrm{a}}$ (National Theatre) } & & \multicolumn{5}{|c|}{ Coefficients (National Museum) } \\
\hline & & \multicolumn{2}{|c|}{$\begin{array}{l}\text { Unstandardized } \\
\text { Coefficients }\end{array}$} & \multirow{2}{*}{$\begin{array}{l}\text { Standar } \\
\text { dized } \\
\text { CoeffiCi } \\
\text { ents } \\
\text { Beta }\end{array}$} & \multirow[t]{2}{*}{$\mathrm{T}$} & \multirow[t]{2}{*}{ Sig. } & \multicolumn{2}{|c|}{$\begin{array}{l}\text { Unstandardized } \\
\text { Coefficients }\end{array}$} & \multirow{2}{*}{$\begin{array}{l}\text { Standardized } \\
\text { CoeffiCients } \\
\\
\text { Beta }\end{array}$} & \multirow[t]{2}{*}{$\mathrm{T}$} & \multirow[t]{2}{*}{ Sig. } \\
\hline & & B & $\begin{array}{l}\text { Std. } \\
\text { Error }\end{array}$ & & & & B & $\begin{array}{l}\text { Std } \\
\text { Error }\end{array}$ & & & \\
\hline & (Constant) & 2.34 & -0.30 & & 7.72 & 0.00 & 3.14 & 0.24 & & 13.38 & 0.00 \\
\hline 1 & $\begin{array}{l}\text { This tourism } \\
\text { destination has its } \\
\text { own website }\end{array}$ & -0.01 & 0.09 & -0.01 & -0.05 & 0.96 & -0.10 & 0.09 & -0.11 & -1.09 & 0.28 \\
\hline 2 & $\begin{array}{l}\text { E-commerce } \\
\text { provide better } \\
\text { information } \\
\text { through the } \\
\text { internet }\end{array}$ & -0.11 & 0.11 & -0.12 & -0.97 & 0.33 & 0.08 & 0.11 & 0.08 & 0.73 & 0.47 \\
\hline 3 & $\begin{array}{l}\text { Use of internet } \\
\text { establish } \\
\text { relationship } \\
\text { between } \\
\text { customers }\end{array}$ & -0.12 & 0.10 & 0.13 & 1.21 & 0.23 & -0.03 & 0.11 & -0.03 & -0.24 & 0.81 \\
\hline 4 & $\begin{array}{l}\text { The internet saves } \\
\text { time for providing } \\
\text { tourism services }\end{array}$ & 0.08 & 0.12 & 0.09 & 0.69 & 0.49 & 0.01 & 0.09 & 0.01 & 0.13 & 0.90 \\
\hline 5 & $\begin{array}{l}\text { It is possible to } \\
\text { book online } \\
\text { packages }\end{array}$ & -0.17 & 0.12 & -0.18 & 1.50 & 0.14 & -0.02 & 0.12 & -0.03 & -0.20 & 0.84 \\
\hline 6 & $\begin{array}{lr}\text { Getting } & \text { Services } \\
\text { through } & \text { internet }\end{array}$ & -0.07 & 0.07 & -0.10 & 1.07 & 0.29 & 0.09 & 0.05 & -0.15 & -1.81 & 0.07 \\
\hline
\end{tabular}




\begin{tabular}{|c|c|c|c|c|c|c|c|c|c|c|c|}
\hline & waste a lot of time & & & & & & & & & & \\
\hline 7 & $\begin{array}{l}\text { Internet saves cost } \\
\text { on accessing } \\
\text { information }\end{array}$ & -0.10 & 0.09 & -0.13 & -1.15 & 0.25 & 0.09 & 0.09 & 0.11 & 1.06 & 0.29 \\
\hline 8 & $\begin{array}{l}\text { The process of } \\
\text { getting services } \\
\text { from destination } \\
\text { is simplified using } \\
\text { online means }\end{array}$ & -0.01 & 0.09 & -0.02 & -0.17 & 0.87 & -0.02 & 0.10 & -0.03 & -0.24 & 0.82 \\
\hline 9 & $\begin{array}{l}\text { The process of } \\
\text { booking } \\
\text { accommodation is } \\
\text { more convenient } \\
\text { than through } \\
\text { travel agents }\end{array}$ & -0.06 & 0.08 & 0.08 & -0.66 & 0.51 & 0.13 & 0.11 & 0.15 & 1.13 & 0.26 \\
\hline 10 & $\begin{array}{l}\text { Possible to access } \\
\text { new products } \\
\text { from the website } \\
\text { of this tourism } \\
\text { destination }\end{array}$ & -0.15 & 0.09 & -0.12 & 1.13 & 0.26 & -0.01 & 0.12 & -0.01 & -0.08 & 0.94 \\
\hline 11 & $\begin{array}{l}\text { Introduce my } \\
\text { friends to e- } \\
\text { commerce for } \\
\text { tourism products } \\
\text { and services }\end{array}$ & -0.03 & 0.12 & 0.04 & 0.04 & 0.78 & -0.09 & 0.11 & -0.10 & -0.87 & 0.39 \\
\hline & & \multicolumn{5}{|c|}{$\begin{array}{l}\text { R. } 0.282 \\
\mathrm{R}^{2} 0.078 \\
\mathrm{R}^{2} \text { adjusted } 0.005 \\
\text { Std error of the estimate } 0.536 \\
\text { F -value } 1.063 \\
\text { F sig. } 0.395\end{array}$} & \multicolumn{5}{|c|}{$\begin{array}{l}R .0 .240 \\
R^{2} 0.558 \\
R^{2} \text { adjusted } 0.417 \\
\text { Std error of the estimate } 0.495 \\
\text { F -Value } 0.769 \\
\text { F sig. } 0.670\end{array}$} \\
\hline
\end{tabular}

a. Dependent Variable: Educational status

b. All requested variable entered.

Source: Researcher's field survey, 2018.

\section{Conclusion}

E-commerce was reasonably adopted for accessing services from National Theatre and National Museum. But, e-commerce was more efficient in the marketing of tourism products and services in National Theatre than National Museum.

In National Theatre "e-commerce provides better information through the internet". "The internet also saves cost on accessing information", as "the process of getting services from destination is simplified using online means" and, tourists will introduce friends to e-commerce for tourism products and services. However, getting services through the internet wastes a lot of time.

The educational status of respondents in both destinations predicted that the use of e-commerce was not efficient in the two destinations.

\section{Recommendations}

The variables that enhanced efficiency of marketing of tourism products and services in National Theatre should be leveraged upon in improving e-commerce transaction in the destination. 
Visitors should be dissuaded of the notion that "getting services through the internet wastes a lot of time". They should be encouraged on the constant use of e-commerce. At the same time, management of the destination should carry out serious overhaul of the e-commerce platform especially in the areas of the constructs that were not significant, so that it can contribute meaningfully to the marketing of services in the destination. For National Museum, management should endeavor to make a paradigm shift from the traditional method of getting customers and marketing to e-commerce in the light of present day internet use.

Other demographic variables such as income, age, gender, etc, should also be used in predicting heritage tourism destination performance vis-à-vis use of e-commerce.

\section{References}

Afuha, A. (2003). "Redefining firm boundaries in the face of the internet: Ate firms really shrinking", Academy of Management Review, 28(1), 34-53.

Alsarayreh, M. N., Jawabreh, O, A. A., Alkharabsheh, K. and Eldahamsheh, M. (2011). "Tourism promotion through the internet: Jordan as a case study", Asian Journal of Social Science, 7(6), 125-135. DOI: 10.5539/ass.v7n6p125

Ayeni, D. A. (2013). "Predicting the effects of economic diversification on sustainable tourism development in Nigeria", American Journal of Tourism Management, 2(1), 15-21. Doi:10.5923/j.tourism.20130201.02

Bello, F. G., Lovelock, B. and Carr, N. (2017). "Constraints of community participation in protected area-based tourism planning: The case of Malawi", Journal of Ecotourism, 16(2), 131-151. https://doi.org/10.1080/14724049.2016.1251444.

Berné, C., García-González, M., García-Ucedac, M.E. and Múgica, J.M. (2015). “The effect of ICT on relationship enhancement and performance in tourism channels", Tourism Management, 48, 188-198.

Boyd, S. (2002). "Cultural and heritage tourism in Canada: Opportunities, principles and challenges", Tourism and Hospitality Research, 3(3), 211-233. https://doi.org/10.1177/146735840200300303

Bramwell, B. (2011). "Governance, the state and sustainable tourism: a political economy approach", Journal of Sustainable Tourism, 9(4-5), 459-477. https://doi.org/10.1080/09669582.2011.576765

Buhalis, D. (1998). "Strategic use of information technologies in the tourism industry", Tourism Management, 19(5), 409-421.

Buhalis, D. (2000). Marketing the competitive destination of the future. Tourism Management, 21: 97-116.

Buhalis, D. (2003). eTourism: Information technology for strategic tourism management, London, Financial Times/Prentice Hall. http://goo.gl/HNCPcb

Candela, G. A. F. P. (2012). The Economics of Tourism Destinations. Berlin, Germany, Springer.

Carlsson, J. (2010). An Assessment of Social Media Business. Retrieved from Diploma in Advanced Strategy. University of Oxford (Saïd) Business School: http://www.opengardensblog.futuretext.com/wp-content/uploads/2010/10/JeanetteCarlsson-AnAssessment-of-Social-Media-Models.pdf 
Chou, M. C. (2013). "Does tourism development promote economic growth in transition countries? A panel data analysis", Economic Modelling, 33, 226-232. https://doi.org/10.1016/j.econmod.2013.04.024

Connelly, R., Gayle, V. and Lambert, P. S. (2016). “A review of educational attainment measures for social survey research", Methodological Innovations, 9. https://doi.org/10.1177\%2F2059799116638001

Corbitt, B. J., Thanasankit, T. and Yi, H. (2003). “Trust and e-Commerce: A study of consumer perceptions", Electronic Commerce Research and Applications, 2(3), 203-215. DOI: 10.1016/S1567-4223(03)00024-3

Dwyer, L. M. N., Forsyth, P., and Rao, P (2001). "International price competitiveness of Australia's mice industry", International Journal of Tourism Research, 3, 123-139.

Dwyer, L., Forsyth, P., Madden, J. and Spurr, R. (2000). “Economic impacts of inbound tourism under different assumptions regarding the macroeconomy", Current Issues in Tourism, 3(4), 325-36.

Ekinci, Y. and Hosany, S. (2006). “Destination personality: an application of brand personality to tourism destinations", Journal of Travel Research, 45(2), 127-139. http://jtr.sagepub.com/cgi/content/abstract/45/2/127

Enz, C. (2003). "Hotel pricing in a networked world", Cornell Hotel and Restaurant Administration Quarterly, 44(1), 4-5. DOI: 10.1016/S0010-8804(03)90030-9

Gilmore, A. and Rentschler, R. (2002) "Changes in museum management: A custodial or marketing emphasis?" Journal of Management Development, 21(10), 745-760. https://doi.org/10.1108/02621710210448020

Gratzer, M., Winiwarter, W. and Werthner, H. (2002). State of the art in e tourism. Proceedings of the $3^{\text {rd }}$ South Eastern European Conference on e-commerce, March 2002, Nikosis, Cyprus.

Harrill, R. and Potts, T. (2003). "Tourism planning in historic districts: Attitudes toward tourism development in Charleston", Journal of the American Planning Association, 69(3), 233-244.

Hoffman, D. L. and Novak, T. B. (1996). "Marketing in hypermedia computer-mediated environments: Conceptual foundations", Journal of Marketing, 60(3), 50-69.

Hoffman, D. L. and Novak, T. P. (1997). "A new marketing paradigm for electronic commerce", The Information Society, 13(1), 43-54. https://doi.org/10.1080/019722497129278

Hoffman, D. L. and Novak, T. P. (1997). “A new marketing paradigm for electronic commerce: The information Society", 13(1), 43-54. https://doi.org/10.1080/019722497129278

Kalakota, R. and Whinston, A. B. (1997). Electronic commerce; A managers guide, New York, Addisson Wesley Publication, Pp. 431.

Kalakota, R., and Robinson., M. (2001). E-business 2.0: Roadmap for success, 2nd ed, Boston, Addison-Wesley.

Kartavianus, O. and Napitupulu, T. A. (2012). "Determining factors on purchasing decision through e-Commerce: A structural equations modelling framework", Procedia Engineering, 50, 463-473. DOI: 10.1016/j.proeng.2012.10.052 
Kayar, C. H. and Kozak, N. (2010). "Measuring destination competitiveness: An application of the travel and tourism competitiveness index", Journal of Hospitality Marketing and Management, 19(3), 203-216.

Kiggundu, J. (2002). Designing e-commerce strategies, Roles of Governments and non-government actors. Prentice Hall.

Lee, G. and Lin, H. (2005). "Customer perceptions of e-service quality in online shopping", International Journal of Retail \& Distribution Management, 33(2), 161-176. https://doi.org/10.1108/09590550510581485

Madasu, P. (2013). Social media marketing and promotion of tourism. Management Insight, 9(1), 71-80.

Manzuma-Ndaaba, N. M., Harada, Y. and Islam, A. (2014). "Challenges to growth in tourism industry of a developing country: The case of Nigeria", Asian Social Science, 10(19), 282290. DOI: $10.5539 /$ ass.v10n19p282

Mason, P. and Cheyne, J. (2000). "Residents' attitudes to proposed tourism development", Annals of Tourism Research, 27, 391-411.

McIvor, R., Humphreys, P. and McCurry, L. (2003). “Electronic commerce: supporting collaboration in the supply chain?" Journal of Materials Processing Technology, 139, 147152.

Metzger, M. J. (2004). "Privacy, Trust, and Disclosure: Exploring Barriers to Electronic Commerce", Journal of Computer-Mediated Communication, 9(4), 00-00. https://doi.org/10.1111/j.1083-6101.2004.tb00292.x

Morgan, N.J., Pritchard, A. and Abbott, S., (2001). "Consumers, travel and technology: A bright future for the web or television shopping", Journal of Vacation Marketing, 7(2), 110-124.

Murphy, L., Mascardo, G. and Benckendorff, P. (2007). “Exploring word-of-mouth influences on travel decisions: friends and relatives vs. other travelers", International Journal of Consumer Studies, 31, 517-527. doi:10.1111/j.1470-6431.2007.00608.x

Noti, E. (2016). "E-commerce as an Added Value in the Tourism Services in Albania", Academic Journal of Interdisciplinary Studies, 5(1), 329-333.

O'Connor, P. and Murphy, J. (2004). "Research on information technology in the hospitality industry", International Journal of Hospitality Management, 23(5), 473-484. DOI: $10.1016 / j . \mathrm{ijhm} .2004 .10 .002$

Paraskevas, A. (2005). The impact of technological innovation in managing global value chains in the tourism industry, in OECD Conference on Global Tourism Growth: A Challenge for SMEs, 6-7 September 2005, in Gwangju Korea. Available at: http://hdl.handle.net/123456789/522, accessed on 23.07.2015.

Pimenidis, E., Bolissian, J.M., Iliadis, L. and Andreopoulou, Z. (2006). E-Readiness or digital exclusion - proposing a new evaluation framework, in Proceedings of the 2nd e-democracy national conference with international participation, Athens, Greece.

Rayman-Bacchus, L. and Molina, A. (2001). "Internet-based tourism services: Business issues and trends", Futures, 33(7),589-605. DOI: 10.1016/S0016-3287(01)00003-9

Schaeffer, A. (2003). E-commercestrategic approaches, New Jersey, Prentice Hall. 
Silberberg, T. (1995). "Cultural tourism and business opportunities for museums and heritage sites", Tourism Management, 16(5), 361-365.

Singer, P., Ferri, M. A., Aeillo, L. and Cacia, C. (2010). "Internet as a point of synergy between communication and distribution: Hypothesis of model applied to tourism", International Journal of Digital Content Technology and its Applications, 4(7), 23-37. DOI: 10.4156/jdcta.vol4.issue7.3

Stiakakis, E. and Georgiadis, K. (2011). "Drivers of a tourism e-business strategy: the impact of information and communication technologies", Operational Research, 11(2): 149-169.

Timmers, P. (1999). Electronic commerce: strategies and models for business-to-business trading, Chichester, Wiley.

Turban, E., King, D., Lee, J. K., Liang, T. and Turban, D. C. (2015). Electronic commerce: A managerial and social networks perspective, in Business and Economics, Switzerland, Springer. DOI 10.1007/978-3-319-10091-3.

Turban, E., King, D., Viehland, D. and Lee, J. (2006). Electronic commerce: A managerial perspective, 4th edition, Pearson, Prentice Hall.

Weber, L. (2007). Marketing to the Social Web. Hoboken, New Jersey, John Wiley \& Sons, Inc.

Werthner, H. and Klein, S. (1999). Information technology and tourism - A challenging relationship. New York, Springer.

Werthner, H. and Ricci, F. (2004). "E-commerce and tourism", Communications of the ACM, 47(12), 101-105. DOI: 10.1145/1035134.1035141

Zhang, H Gu, C. L., Gu, L. W. and Zhang, Y. (2011). “The evaluation of tourism destination competitiveness by TOPSIS \& information entropy - A case in the Yangtze river delta of China", Tourism Management, 32(2), 443-451.

Zhou, Q. and DeSantis, R. (2005). “Usability issues in city tourism website design: A content analysis", Professional Communication Conference, 2005. IPCC 2005. DOI: 10.1109/IPCC.2005.1494253.

https://www.researchgate.net/deref/http $\% 3 \mathrm{~A} \% 2 \mathrm{~F} \% 2$ Fieeexplore.ieee.org $\% 2 \mathrm{Fxpl} \% 2 \mathrm{Ffre}$ eabs_all.jsp\%3Farnumber\%3D1494253 